\title{
The transcriptional co-activator p/CIP binds CBP and mediates nuclear-receptor function
}

\author{
Joseph Torchia ${ }^{\star}$, David W. Rose $\dagger$, Juan Inostroza ${ }^{\star}$, Yasutomi Kamei ${ }^{\star}$, Stefan Westin $\ddagger$, Christopher K. Glass $\ddagger$ \\ \& Michael G. Rosenfeld*
}

${ }^{*}$ Howard Hughes Medical Institute, $\dagger$ UCSD Department of Medicine and Whittier Diabetes Program, $¥$ Cellular and Molecular Medicine, School and Department of Medicine, University of California, San Diego, 9500 Gilman Drive, La Jolla, California 92093-0648, USA

\begin{abstract}
The functionally conserved proteins CBP and p300 act in conjunction with other factors to activate transcription of DNA. A new factor, p/CIP, has been discovered that is present in the cell as a complex with CBP and is required for transcriptional activity of nuclear receptors and other CBP/p300-dependent transcription factors. The highly related nuclear-receptor co-activator protein NCoA-1 is also specifically required for ligand-dependent activation of genes by nuclear receptors. p/CIP, NCoA-1 and CBP all contain related leucine-rich charged helical interaction motifs that are required for receptor-specific mechanisms of gene activation, and allow the selective inhibition of distinct signaltransduction pathways.
\end{abstract}

CBP and p300 are functionally conserved proteins that have intrinsic acetylase activity ${ }^{1,2}$ and are essential for the activation of transcription by a large number of regulated transcription factors, including nuclear receptors (refs 3-6), CREB (refs 7, 8), AP-1 (ref. 8), bHLH factors (ref. 9) and STATs (refs 10-12). Nuclear receptors are a large family of ligand-dependent transcription factors that bind as homodimers or heterodimers to their cognate DNA elements ${ }^{13-15}$ and regulate genes involved in critical aspects of cell proliferation, differentiation and homeostasis. Transcriptional regulation by nuclear receptors depends primarily upon a liganddependent activation function, AF-2, located in the carboxy terminus and predicted to undergo an allosteric change upon ligand binding $^{16-22}$, although additional amino-terminal activation functions operate for many receptors. Consistent with this, CBP and p300 have been found to interact directly with nuclear receptors in a ligand- and AF-2-dependent manner.

In addition to CBP and p300, a series of factors that exhibit ligand- and AF-2-dependent binding to nuclear receptor $\mathrm{C}$ termini have been identified biochemically ${ }^{3,23-25}$ and by expression cloning $^{3-6,27-32}$. Two homologous factors, SRC-1/NCoA-1 and TIF-2/ GRIP-1, which increase ligand-dependent transcription by several nuclear receptors in co-transfection assays ${ }^{1,30,31}$, constitute a nuclear receptor co-activator $(\mathrm{NCoA})$ gene family ${ }^{1,30,31}$. These findings have raised intriguing questions of whether NCOA-1, CBP or other p160 family members are required for ligand-dependent gene activation.

Here we report the cloning and characterization of a new NCoA/ SRC family member, p/CIP, which complexes with a significant portion of CBP in the cell. Surprisingly, both p/CIP and NCoA-1 are required for the function of nuclear receptors, whereas $\mathrm{p} / \mathrm{CIP}$, but not NCoA-1, is required for the function of other CBP-dependent transcription factors. A series of helical leucine-charged residuerich domains (LCDs) serve as interaction motifs within these factors and are required for the assembly of a co-activator complex and provide specificity of nuclear-receptor activation.

\section{New members of the NCoA family}

Our initial expression screening strategy for identifying members of the p160 gene family was based on the observation that the biochemically identified p160 proteins interact with a 100-aminoacid region in the $\mathrm{C}$ terminus of $\mathrm{CBP}$ (residues 2,058-2,170), as well as with the liganded oestrogen receptor ${ }^{1}$. This enabled us to isolate previously described NCoA-1/SRC-1 protein and a second related factor, NCoA-2 (Fig. 1a), which has a relative molecular mass of $159.6 \mathrm{~K}$ and seems to be the murine homologue of human TIF-2 (ref. 30), part of which has been reported as GRIP-1 (ref. 31). In addition, we identified a related factor which we term p/CIP (for p300/CBP/co-integrator-associated protein) (Fig. 1a).

$\mathrm{p} / \mathrm{CIP}$ is a $152 \mathrm{~K}$ protein which is highly related to SRC- $1 / \mathrm{NCoA}-1$ and NCoA-2/TIF-2, having an overall amino-acid identity of $31 \%$ and $36 \%$, respectively (Fig. 1d). p/CIP harbours a fairly well conserved N-terminal bHLH, PAS A domain (50-60\% aminoacid identity), a serine/threonine-rich region, and a C-terminal glutamine-rich region, which are also present in NCoA-1 and NCoA-2. Western blot analysis indicates that p/CIP, NCoA-1 and $\mathrm{NCoA}-2$ are widely expressed in adult tissues and in all cell lines tested (Fig. 1b,c).

\section{A CBP/pCIP complex}

To evaluate the association of p/CIP, NCoA-1 and NCoA-2 with $\mathrm{CBP}$ and nuclear receptors, a glutathione $S$-transferase fusion protein (GST) with CBP (residues 2,058-2,170) was used to affinity-purify interacting proteins from HeLa cell extract. p/CIP was consistently observed by immunoblotting using affinitypurified anti-p/CIP IgG, whereas much smaller amounts of NCoA-1 were detected by immunoblotting with anti-NCoA-1 IgG (Fig. 2a). Similarly, immunoprecipitations from whole-cell extracts using excess antiserum selective for each protein, followed by immunoblotting with anti-CBP/p300 antibody demonstrated that the vast majority of $\mathrm{CBP} / \mathrm{p} 300$ co-precipitated with the new factor p/CIP, although small amounts of NCoA-1- and NCoA-2associated CBP could be detected (Fig. 2b). Conversely, the amount of $\mathrm{CBP} / \mathrm{p} 300$ remaining in the supernatant fraction following immunodepletion with anti-NCoA-1 IgG remained unchanged, but a significant fraction of $\mathrm{CBP} / \mathrm{p} 300 \mathrm{CBP}$ was removed by immunodepletion with anti-p/CIP IgG (Fig. 2b). These results indicated that $\mathrm{p} / \mathrm{CIP}$ could form a complex with $\mathrm{p} 300 / \mathrm{CBP}$ in the cell.

To define the CBP-interaction domain in p/CIP, we generated deletion mutants and tested against CBP (amino acids, 2,0582,170 ) by a yeast two-hybrid assay. The major CBP interaction 
a

p/CIP NCOA-2

100 MSGLGESSLDPLAAESRKRKL PCDAPGQGLVYSGEKWRREQESXYYEELAELISANLSDIDNFNVKPDKCAILKETTVRQIRQIKEQGKTISSD. DDVQRA 99

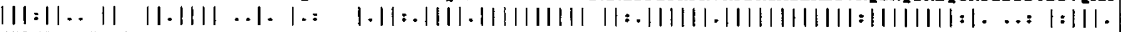
MSGMGENTSDPSRAETRKRKECPDQLGP SPKRSTEKRNREQENKY IEELABLIFANFNDIDNFNFKPDKCAILKETVKQIRQIKEQEKAAANIDEVQKS 100

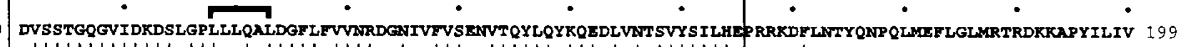

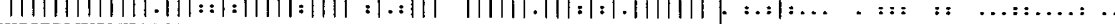

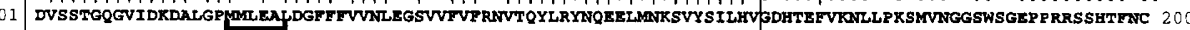
200 FMLMKT. HDILEDVNASPETRQRYETMQCFALSQPRAMLEEGEDLQCCMICVARRVTAPPPSSPESFI.......TRHDLSGKVVIIDTVSLRSSMRP 289 1 RMLVKPLPDSEEGHDSQEAHQKYEAMQCFAVSQPXS IXEEGEDLQSCLI. . VWHEDPHEGKTNSSLIRKLYHP PGPPRQDHFTGHYHHESRHEAGLGRS 298

290 GFEDT IRRCIQRFFSLNDGQSWSQKRHYQEAYVHGHAETPVYRFSLADGTIVSAQTKSRLFRNPVTANDHGFISTKFLQREQNGYRPAPIPQDKGI... 385

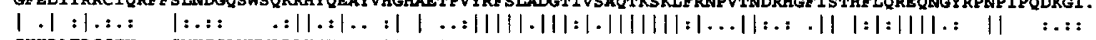

299 GKKDAFRSSTH. . SMKGSLYHMPRRHHEVLROGLAFSQTYRFSLSDGTLVAAQTKSKLIRSQTTTEEQQLVISLHMLHREQNVCVMNPDLTGQAMGKPL 395

386 .....RPPAAGCGVSMSPNQNVQMMGSRTYGVPDPSMTGQMGGARYGASSSVASLTPGQSLQSPSSYQNSSYGLSMSSPPHGSPGLGPNQQNIMISPRNR 480

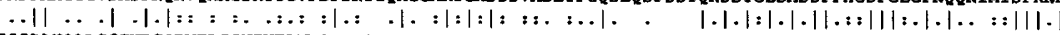

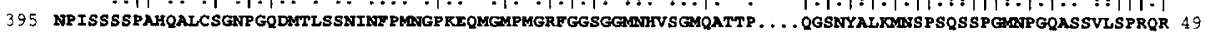

481 ..... GSPKMASHQFSPAAGAHSPMGPSGITG. SHSFSSSSLSALQAISEGVGTSLLSTLSSPGPKLDA. . . SPMANISQPSKVSGQDSKSPLGLYCE 569 ||$|:::|||||:. .|||:| .:: .|||||: \ldots||| .||||:||||-|||| .||:.|::| \quad \ldots|||\ldots||:::||| \ldots:|| \mid$.

492 MSPGVAGSPRIPPSOFSPAGNLHS PVGVCSSTGNSHSYTXSSLNALOALSEGBGVLGSSLASPDLKMGNLONSPVNDONPPPLSKMGSLDSKDCFGLYGE 591 Nuclear Receptor Interaction Domain -

570 Q.... NPVESSVCQSNSRDPQVKKESKESSGEVSETPRGPLISKGHKKLLQLLTCSSDDRGHSSLTNSPLDPNCKDSSVSVTSPSGVSSSTSGTVSSTS 66

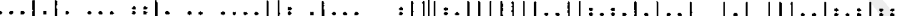

592 PSKGTTGQAZASCHPKKQKGPNDSSMPQAASGDRAEGHSRLHDSKGQTKLLQLLTTKSDQMEPSPLPSSLSDTN. KDSTGSLPGPGS......... 677

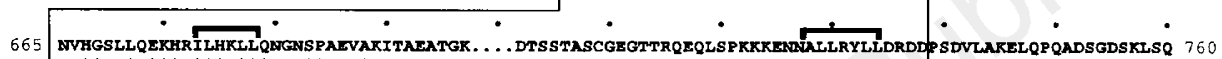

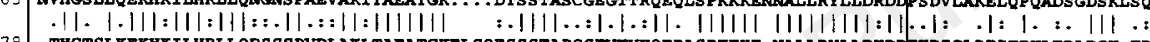

678 .THGTSLKEKHKILHRLLODSSSPVDLAKL,TAEATGKELSQESSSTAPGSEVTVKQEPASPKKKE. NALLRYLLDDDTKDIGLPEITPKLERLDSX.TD 774

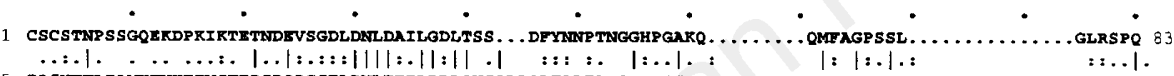

775 PASNTKLIANGTVKEEVSFEPSDQPGSELDNLEEILDDLQNSQLPQLFPDTRPGAPTGSVDKQAIINDLMQLTADSSPVPPAGAQKANLCMSOSSFMNPR 874

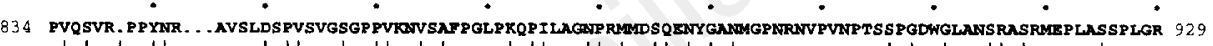

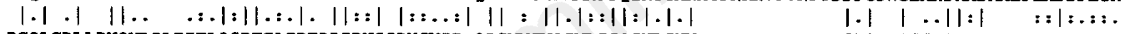

75 PGQLGRLLPYQNLPLDITLQSPTGAGPFPPIRNSSPYSVIP.QPGMMGRQGMGGQGRLGM............ STGMIGSSTSRPS....MPSGEWAP 956 Core CBP Interaction Domain

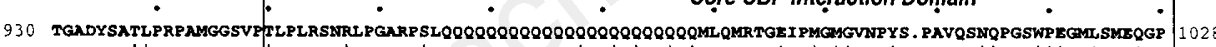

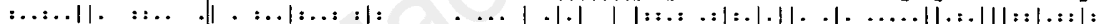

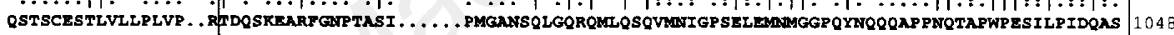

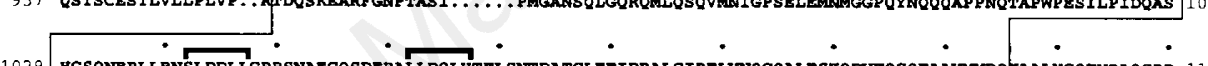

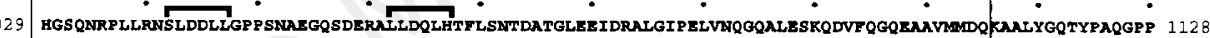

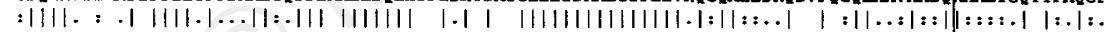
1049 FASQNRQPFGSSPDDLLCPHPANSPSDEGALLDQLYLALRNFD. . GLEIIDRALGTPELVSQSQAVDAEQ. FSSQESSIMLEQKPPVFPQYASQAQM 1144

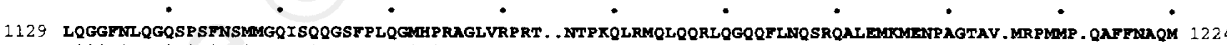

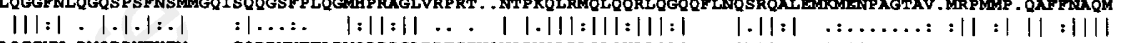

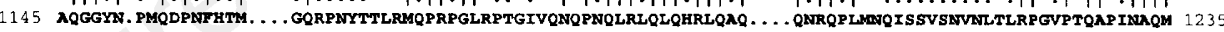

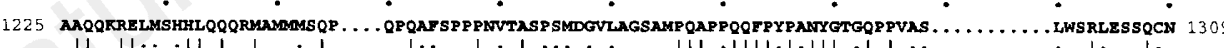

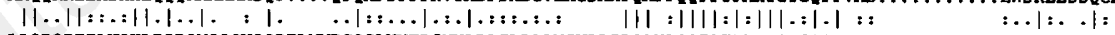

1236 LAQRQREILNQHLRQRQMQQQVQQRTLMARGQGLNVTPSMVAPAGLPAAMSNPRIPQANAQQFPFPPNYGISQQPDPGFTGATTPQSPLMSPRMAHTQSP 1335

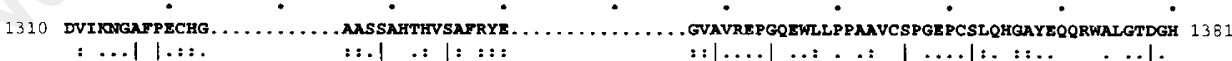

1336 MMQQSQANPAYQPTSDHNGWAQGSMGGNSMF $Q Q S P$ PHFGQQANTSMYSNAMANI SVSMATNTGGLSSMONOMTGQMSMTSVTSVPTSGLPSMGPEQVVDPA 1435

1382 DPHAHVWHAHGPRSETLLTS

: ::::,: $:::$ :

1436 LRGGMLPNQLLGMDMIKQEGDASRKYC

1402

1463
Figure 1 Characterization of a CBPassociated factor $(p / C I P)$ and a related member of the $\mathrm{NCOA}$ family (NCoA-2). a, Comparison of the primary amino-acid sequences of $\mathrm{p} / \mathrm{CIP}$ and NCoA-2. The conserved bHLH, PAS A domain, the nuclearreceptor-interaction domains and the minimal nuclear-receptor and CBP interaction domains are boxed, and repeat motifs involved in critical interactions are bracketed. b, c, Western blot analysis of total cell extracts for $\mathrm{p} / \mathrm{CIP}, \mathrm{NCOA}-1$ and NCOA-2 in various tissues and cell lines; there is widespread expression of all three proteins, but relative levels differ. d, Diagram of $\mathrm{p} / \mathrm{CIP}$, showing regions of homology with NCoA-1 and NCoA-2. Asterisks refer to the repeated peptide motifs that appear to be functionally important (Figs 5, 6). b

$\mathrm{p} / \mathrm{CIP}$

NCOA-1
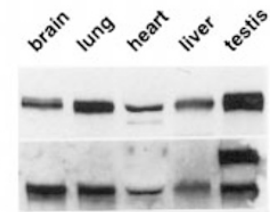

NCOA-2

d

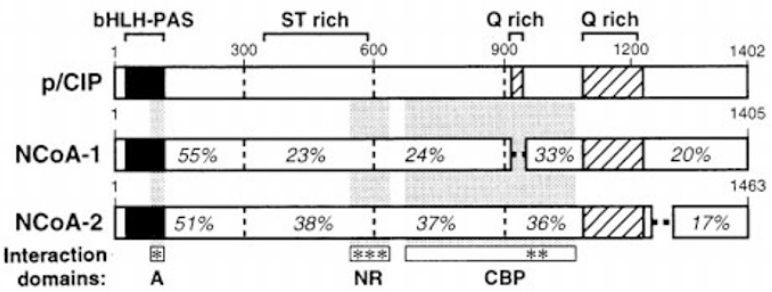

c

p/CIP

NCOA-1

NCoA-2 $=-$ domains:

NR

CBP
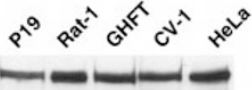

domain was located between residues 758 and 1,115 , with an internal 200-amino-acid domain that could still interact. We observed a less pronounced interaction with the N-terminal region containing the PAS A domain (Fig. 2c). A single nuclearreceptor-interaction domain (residues 591-803) was localized Nterminal of the $\mathrm{CBP} / \mathrm{p} 300$ interaction domain (Fig. 2c). Further mapping delineated a minimal nuclear-receptor-interaction region encompassing amino acids 680-740 in p/CIP which were sufficient for binding to the liganded nuclear receptors (data not shown). Comparable regions in $\mathrm{NCoA}-1$ and $\mathrm{NCoA}-2$ were found to mediate interactions with both $\mathrm{CBP} / \mathrm{p} 300$ and nuclear receptors (Fig. 2d, and data not shown). GST pull-down assays of whole-cell extracts revealed that $\mathrm{p} / \mathrm{CIP}, \mathrm{NCoA}-1$ and NCoA-2 interacted with GST fusion proteins with the oestrogen receptor (GST-ER) and the retinoic acid receptor (GST-RAR) in a ligand-dependent manner (Fig. 2e). 
a

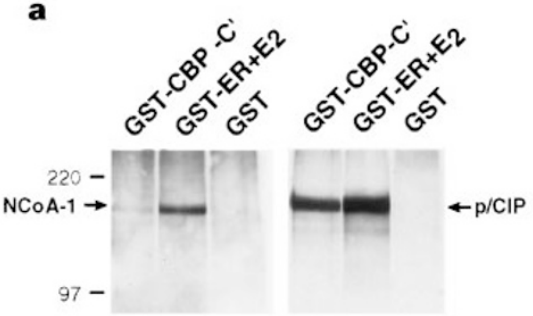

b

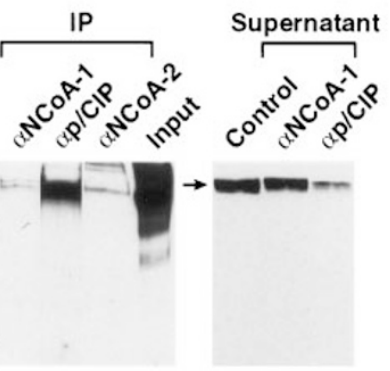

c
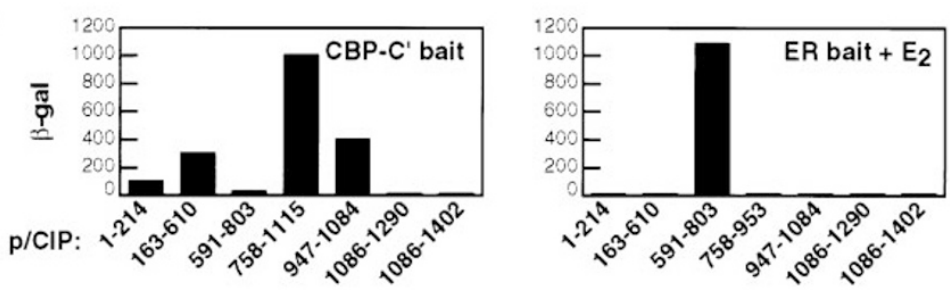

d

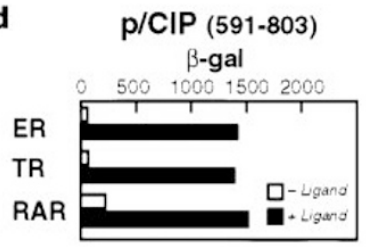

NCoA-1 (570-833) $\beta$-gal
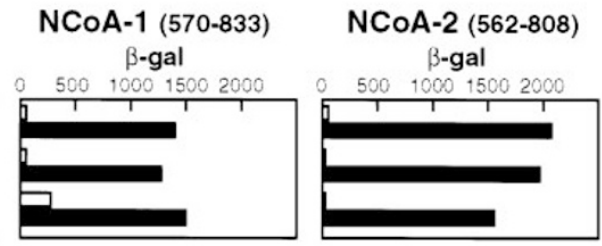

$\mathbf{e}$

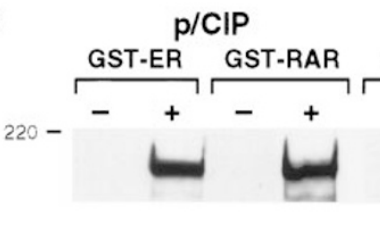

f

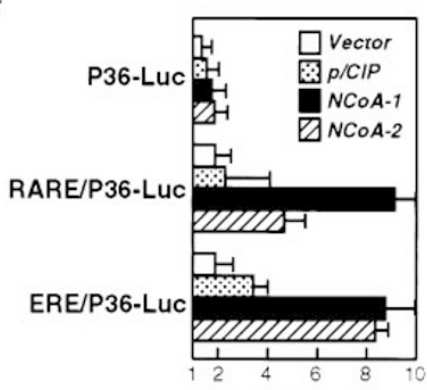

Fold activation
NCOA-1

NCoA-2

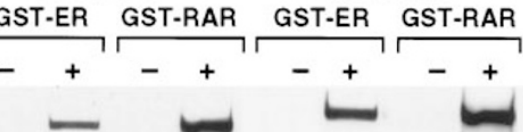

Figure 2 Biochemical analysis of p/CIP and NCoA factors. a, Interaction between recombinant GST proteins and NCoAs from HeLa whole-cell extracts detected using an antibody against $\mathrm{p} / \mathrm{CIP}$ (left) or NCoA-1 (right). b, Left, co-immunoprecipitation of CBP/p300 and p/CIP. Anti-p/CIP, NCoA-1 or NCoA-2 IgG were incubated with HeLa whole-cell extracts and immunocomplexes were separated by SDS-PAGE and probed using anti-CBP/p300 lgG; right, detection of CBP/p300 in supernatant following immunodepletion of whole-cell extracts with specific anti-NCoA antibodies. c, Yeast two-hybrid assay mapping regions of interaction between $\mathrm{p} / \mathrm{CIP}$ and $\mathrm{CBP} C$ terminus (amino acids 2,058-2,170) and liganded nuclear receptors (LBD). d, A common nuclear-receptor-interaction domain is found in $\mathrm{p} / \mathrm{CIP}, \mathrm{NCOA}-1$ and NCOA-2 by yeast twohybrid assays. Ligands $(+)$ were oestradiol $\left(10^{-6} \mathrm{M}\right)$, Triac $\left(10^{-6} \mathrm{M}\right)$ and retinoic acid $\left(10^{-6} \mathrm{M}\right)$. e, p/CIP, NCoA- 1 and $\mathrm{NCoA}-2$ interactions with nuclear receptors in vitro. Recombinant GST-nuclear-receptor proteins were incubated with whole-cell extract in the presence(+) or absence $(-)$ of ligand, and western-blotted using p/CIP-, NCoA-1- or NCoA-2specific IgG. f, Reporters containing the minimal prolactin promoter (P-36 luciferase) alone or 2 copies of the indicated response elements and expression plasmids expressing p/CIP, NCoA-1 or NCoA-2 were transfected into HeLa cells in the presence of the corresponding ligand. Right, effects of varying amounts of plasmid expressing GAL4(1-147), GAL4NCoA-1 or GAL4-p/CIP fusion proteins on a minimal (UAS) - $^{-}$ dependent reporter.
Co-transfection with NCoA-1/SRC-1 or NCoA-2/TIF-2 expression vectors potentiated ligand-dependent activation (generally three- to eightfold), whereas co-transfection with p/CIP expression plasmids resulted in minimal or no activation effect (Fig. $2 \mathrm{f}$, left). In addition, when full-length cDNAs were fused to GAL4(1-147), the activation observed by GAL-NCoA-1 was significantly stronger than GAL-p/CIP (Fig. 2f, right). Co-transfection of CBP and NCoA1 or NCoA-2 expression vectors resulted in variable synergy (data not shown), consistent with findings reported for SRC-1 (ref. 33).

\section{Nuclear receptors require $\mathrm{p} / \mathrm{CIP}$ and NCoA-1}

To investigate the function of p/CIP, NCoA- 1 and NCoA-2, we used microinjection techniques with affinity-purified IgGs. Reporter genes were placed under the control of a minimal promoter containing either nuclear receptor or other response elements, as described $^{3}$. Microinjection of anti-p/CIP IgG prevented retinoic acid from activating a retinoic-acid receptor (RAR)-dependent transcription unit (Fig. 3a), but had no effect on a promoter under the control of SP-1 elements or the cytomegalovirus (CMV) promoter. In similar experiments, we found that $\mathrm{p} / \mathrm{CIP}$ was also required for the actions of oestrogen, thyroid-hormone and progesterone receptors (Fig. 3b).

To determine whether depletion of CBP, rather than p/CIP itself, was responsible for the observed effects, we next evaluated the relative abilities of p/CIP, CBP, NCoA-1 and/or NCoA-2 to rescue the inhibitory effect of anti-p/CIP IgG. No factor alone, including CBP, was able to rescue the inhibition by anti-p/CIP IgG of RARdependent transcription, indicating that stearic blockage or removal of CBP did not account for the observed effects. However, the simultaneous expression of both $\mathrm{p} / \mathrm{CIP}$ and CBP fully restored the retinoic-acid transcriptional response in anti-p/CIP-treated cells (Fig. 3c). Therefore CBP and $\mathrm{p} / \mathrm{CIP}$ are required together for nuclear-receptor activation. To confirm this strict requirement for $\mathrm{p} / \mathrm{CIP}$, the action of a 137-amino-acid region of $\mathrm{p} / \mathrm{CIP}$ (residues 947-1084) containing the core CBP-interaction domain was tested by microinjection assay, resulting in complete inhibition of the retinoic-acid-dependent gene activation (Fig. $3 \mathrm{~d}$, left). In contrast, this fragment did not block the activity of non-CBP-dependent promoters (Fig. 3d, right).

We next investigated whether p/CIP might also be required for 

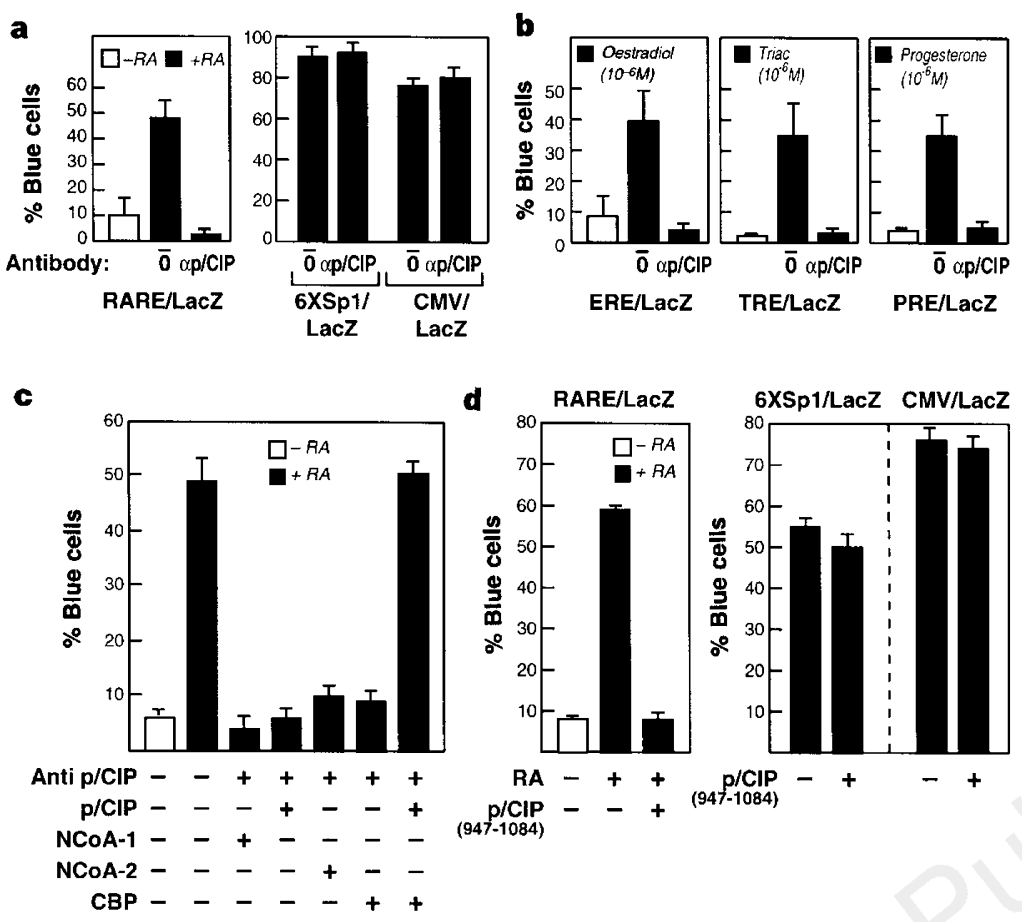

d RARE/LacZ GXSP1/LacZ CMV/LacZ

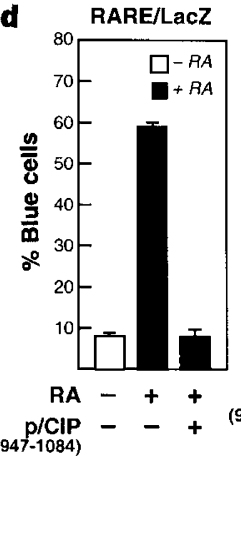

Figure 3 Role of P/CIP in function of CBP-dependent transcription factors. a, Effects of microinjection in Rat-1 cells of affinity-purified anti-p/CIP IgG on ligand-dependent gene activation by RAR. b. Similar experiments with minimal promoters with four copies of the oestrogen- (ERE), thyroidhormone (TRE) or progesterone (PRE)-receptor response elements. c, Requirement for both CBP and p/CIP expression vectors to rescue anti-p/CIP IgG inhibition of RARdependent gene activation. d, Effects of expression of the $\mathrm{p} / \mathrm{CIP}$ core CBP interaction domain $(947-1,084)$ on RAR (left), and SP-1 or CMV(right)-dependent transcription. e, Effects of anti-p/CIP IgG ( $\alpha \mathrm{p} / \mathrm{CIP})$ on an IFN $\gamma$-dependent promoter (GAS/LacZ) ${ }^{12}$ (left). Effects of p/CIP (residues 9471,084) on IFN $\gamma$-stimulated transcriptions and failure of CBP expression vector to rescue this inhibition (right). f, Effects of anti-NCoA-1 IgG ( $\alpha$ 1) on GAS and cAMP-dependent $(2 \times \mathrm{CRE})$ promotors. Experiments were done at least three times, with $>200$ cells injected; error bars are $\pm 2 \times$ s.e.m.

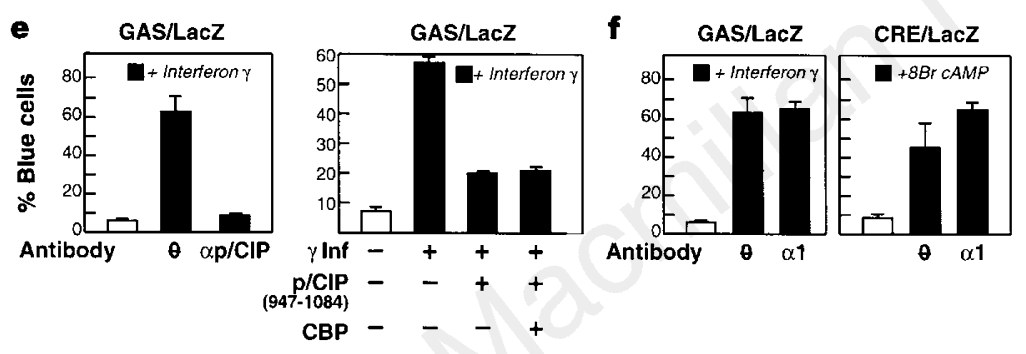

transcriptional activation by other CBP-dependent transcription factors, such as STATs ${ }^{10-12}$. Therefore the effects of anti-p/CIP and NCoA-1 IgG were evaluated by immunoinjection assay in cells, initially using interferon (IFN)- $\gamma$-dependent reporters or reporters dependent on TPA (12-O-tetradecanoylphorbol-13-acetate). Antip/CIP IgG entirely inhibited STAT-dependent and TPA-dependent transcriptional activation events (Fig. 3e, and data not shown), which was not restored by overexpression of CBP alone (data not shown). Independent confirmation was provided by overexpression of the CBP-interaction domain of p/CIP (residues 947-1,084), which blocked the stimulation of transcription by interferon- $\gamma$ or TPA (Fig. 3e, and data not shown). C-terminally truncated CBP failed to enhance either IFN- $\boldsymbol{\gamma}$ - or TPA-dependent transcription in co-transfection assays (data not shown), and could not rescue the block of retinoic-acid and IFN $\gamma$-dependent gene activation by injected anti-CBP $\operatorname{IgG}^{3,12}$ (data not shown). These results indicate that $\mathrm{p} / \mathrm{CIP}$ and $\mathrm{CBP}$ are a functional complex, necessary for the activity of several CBP-dependent transcription factors as well as nuclear receptors.

\section{Roles of NCoA-1 and NCoA-2}

As $\mathrm{p} / \mathrm{CIP}$ is required by nuclear receptors and several CBP/p300dependent transcription factors, we evaluated the roles of NCoA-1/ SRC-1 and NCoA-2/TIF-2, which by co-transfection enhance transactivation by nuclear receptors. Microinjection of antiNCoA-1 IgG, but not anti-NCoA-2 IgG, effectively inhibited retinoic-acid-dependent transcription (Fig. 4a), whereas these antisera failed to inhibit several control promoters lacking nuclearreceptor response elements (Fig. 4a). In addition, anti-NCoA-1 IgG fully inhibited oestrogen- and thyroid hormone-receptor stimula- tion (Fig. 4b) and partly inhibited progesterone-receptor stimulation (Fig. 4b). Co-injection of NCoA-1, NCoA-2 or p/CIP expression vectors revealed that the inhibitory effects of antiNCoA-1 IgG could be reversed by either NCoA-1 or NCoA-2, but not by p/CIP (Fig. 4c), consistent with a distinct role for this factor, and in contrast to the requirement for both $\mathrm{p} / \mathrm{CIP}$ and CBP to rescue inhibition by anti-p/CIP IgG. Co-injection of a CMV-CBP expression vector also failed to restore activity, consistent with the idea that both NCoA-1 and the CBP/p300/p/CIP complex are independently required for nuclear-receptor gene activation (Fig. 4c). In contrast, anti-NCoA-1 IgG exerted no effects on either cAMP- or IFN $\gamma$-dependent reporters (Fig. 3f). These observations suggest that NCoA-1 is selectively required as a co-activator for the ligandactivated nuclear receptor gene expression events, while the requirement for the $\mathrm{p} 300 / \mathrm{CBP} / \mathrm{p} / \mathrm{CIP}$ complex seems to reflect a more general obligatory role in gene activation events.

\section{Inhibition by motifs of the p/CIP complex}

Because of the striking relatedness of NCoA-1 and p/CIP, despite their different function, and the activation by CBP/p300 of different classes of transcription factors, we investigated whether distinct interaction domains could selectively block the actions of specific signal-transduction pathways in the nucleus. The nuclear-receptor interaction domains of $\mathrm{p} / \mathrm{CIP}$, NCoA- 1 and NCoA-2 have revealed the presence of highly conserved LCDs that share a consensus core LXXLL sequence motif (Fig. 5a). This motif is found in both the nuclear-receptor and $\mathrm{p} / \mathrm{CIP}$-interaction domains of CBP, and in the CBP-interaction domain of $\mathrm{p} / \mathrm{CIP}$. Analysis of these interaction regions by the self-optimized prediction method $^{34}$ indicates that they are helical domains, generally with amphipathic characteristics 

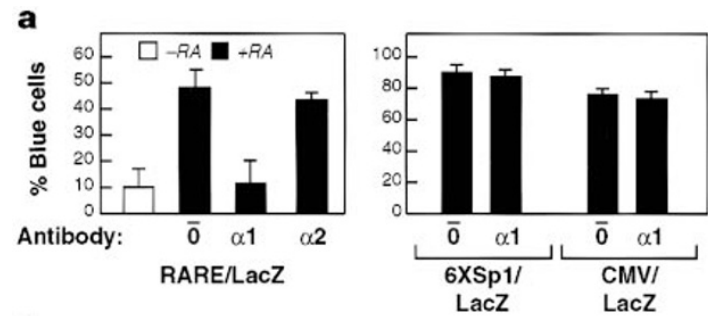

b
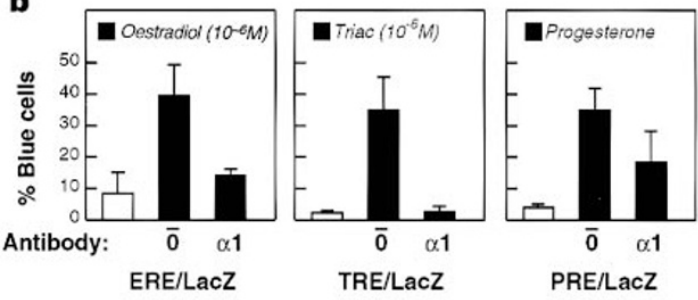

d
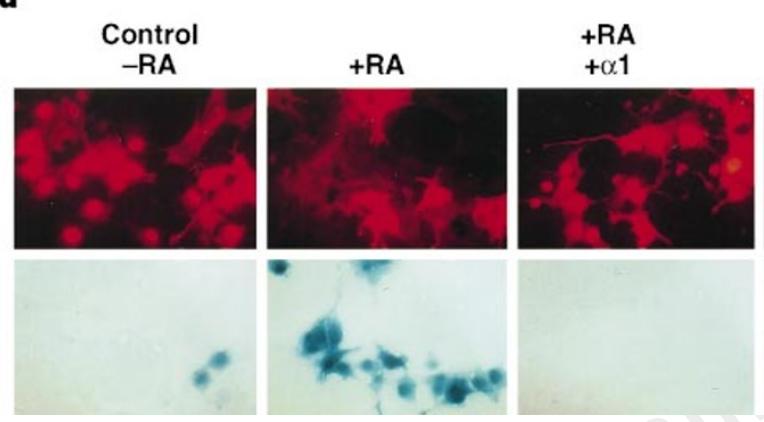

C
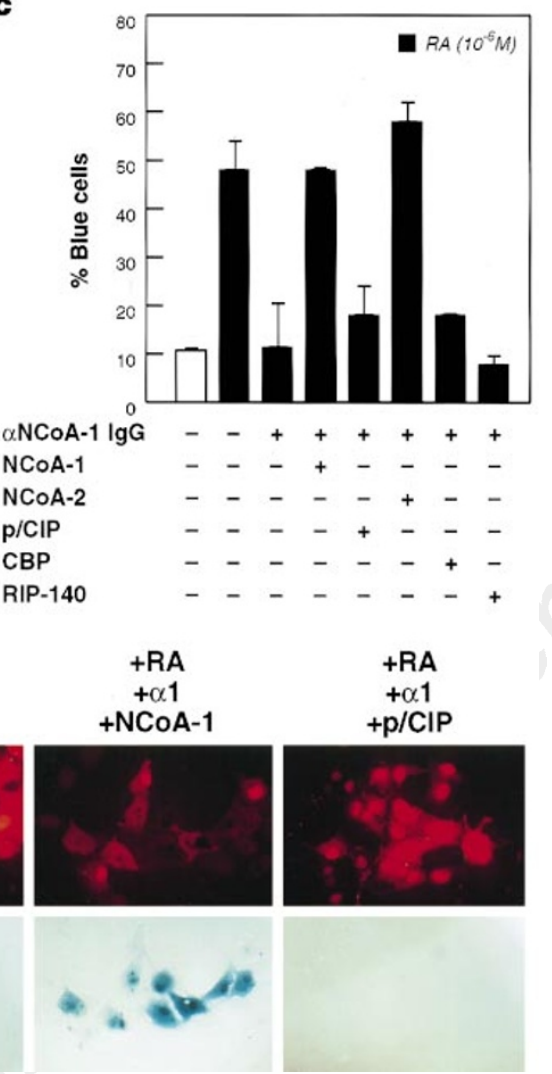

Figure 4 Role of NCoA-1 and NCoA-2 in nuclear receptor function. a, Microinjection of affinity-purified antiNCoA-1, but not anti-NCoA-2 lgG blocked ligand-dependent gene activation by RAR (left) and did not inhibit expression of either the $6 \times \mathrm{SP}-1$ or CMV-driven promoters (right). b, Results were similar using minimal promoters with two copies of the oestrogen (ERE) or T3R (TRE) response elements, with effects being less profound on progesterone(PRE)mediated transcription. c, Anti-NCoA-1 IgG blocked retinoic-acid-dependent activation of the RARE/LacZ reporter, and was not rescued by CMV expression vectors expressing $\mathrm{p} / \mathrm{CIP}$ or $\mathrm{CBP}$; expression was fully rescued by either CMVNCoA-1 or CMVNCoA-2. d, Photomicrographs of rhodominestained injected cells and the corresponding protein of $\mathrm{X}$-gal staining.
(Fig. 5a). We tested these LCDs for a critical interaction function by introducing four amino-acid mutations of this motif into the $\mathrm{N}$ terminus of CBP (residues 65-76), which abolishes interactions with nuclear receptors (Fig. 5b). The minimal nuclear-receptorinteraction domain of NCoA-1 contains three such helical domains, and a fourth domain (LCD6) is also present in a variant of NCoA-1 (refs 3, 29). To assess the importance of these domains in NCoA-1, a smaller region lacking helical domain 3 gave little or no decrease in binding to either oestrogen or retinoic-acid receptors; deletion of helical domain 1 gave a small but significant decrease (Fig. $5 c$ ). In contrast, a four-amino-acid substitution in the second NCoA-1 helical domain (LCD2, HRLL $\rightarrow$ AAAA), which alters the properties of this helix, abolished interaction with both oestrogen and retinoic-acid receptors. Conversely, a 37-amino-acid region of NCoA-1 containing LCD2, or a 59-amino-acid region containing LCD6, was sufficient for binding to liganded nuclear receptors (Fig. 5c, left). An excess of 24-amino-acid oligopeptide encompassing LCD2 effectively blocked interaction between liganded RAR and NCoA-1 in vitro, but a peptide corresponding to LCD1 was less effective. These results show that specific motifs can be both necessary and, in certain instances, sufficient for interaction.

To test for selective functional requirements of these helical motifs in the nuclear-receptor-interaction domain of NCoA-1, we generated mutations in helical domains 2 or 3 in the holoprotein, and determined whether they could rescue the antiNCoA-1 IgG inhibition of retinoic-acid receptor. Wild-type NCoA-1 rescued activation, but a NCoA-1 holoprotein with clustered point mutations in helical domain 3 (LCD3-mut) was unable to rescue retinoic-acid receptor function. NCoA-1 containing a helical domain 2 (LCD2-mut) mutation retained some effect (Fig. 5d), consistent with the residual ability of the helical domains to mediate nuclear-receptor interactions. Surprisingly, LCD3-mut was fully functional in oestrogen-receptor-dependent gene activation, whereas LCD2-mut was now ineffective at rescuing oestrogen-receptor function (Fig. 5e). These results suggest that the helical interaction motifs of NCoA-1 afford a level of receptor specificity.

To evaluate the importance of these motifs, we tested the corresponding peptides for their ability to inhibit specific activation. NCoA-1 contains two additional related helical interaction motifs, and a peptide encompassing one of these (LCD4) can block nuclear-receptor transcription factor function and does not impair STAT function (Fig. 6a). Furthermore, a mutation in this motif impairs the function of this region in $\mathrm{p} / \mathrm{CIP}$ (data not shown). Thus, specific signal transduction pathways could be selectively blocked by different helical interaction motifs.

We therefore investigated whether other motifs, not required for nuclear-receptor activation, might also be critical for co-activator function for other classes of CBP-dependent transcription factors, selectively blocking different signal-transduction pathways. Taking advantage of the fact that there is a critical STAT interaction domain within the first 100 amino acids of $\mathrm{CBP}^{12}$, we determined whether a sequence of the CBP N-terminal 100 amino acids, distinct from the nuclear-receptor domain, might mediate interaction with STAT-1 and also be required for STAT function. We evaluated the effects of peptides corresponding to N-terminal regions of CBP on STAT-1 or retinoic-acid receptor function and found a synthetic peptide against the N-terminal 22 amino acids of CBP (CBP N'P1; Fig. 6b) that markedly inhibited IFN $\gamma$-dependent gene activation but had no effect on the retinoic-acid receptor. The identical peptide, from which the N-terminal seven amino acids (MAENLLY) were deleted, abolished this effect (CBP N'P2; Fig. 6b), suggesting that this sequence encompassed a motif required for STAT interaction and function. Our results support the functional significance of the STAT-1 interaction motif already identified in the CBP N terminus ${ }^{12}$.

We also tested whether the CBP N-terminal peptide could selectively block the inhibitory effects of STAT-1 or retinoic-acidreceptor-dependent transcription by evaluating its effects on stimulation by IFN- $\gamma$ and retinoic acid. The simultaneous addition 


\section{a}

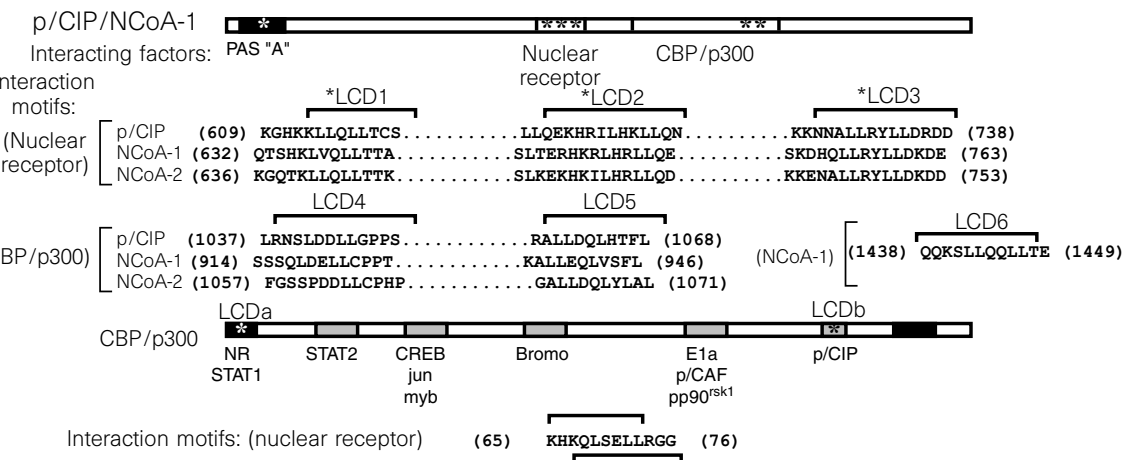

Interacton moliss. (nuclear receptor) (65) KATELSELLRGe (76)
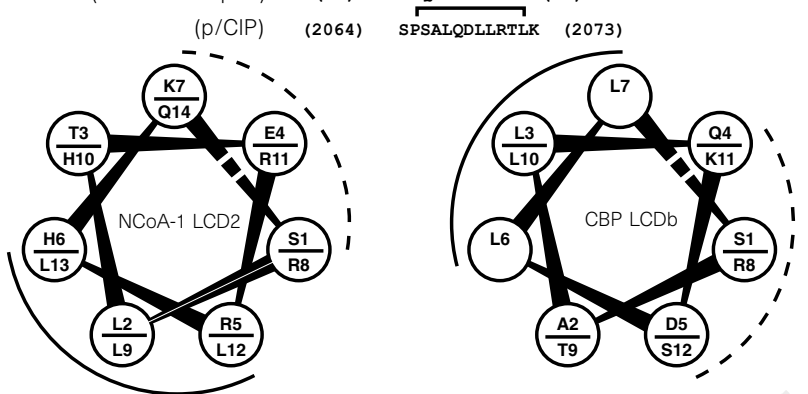

b

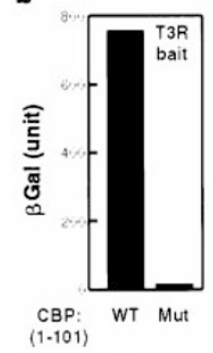

c

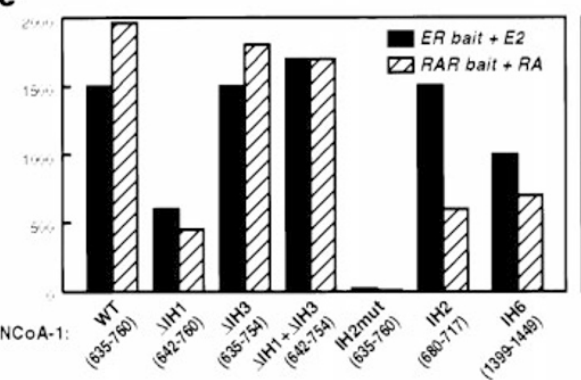

Figure 5 Leucine charged domains (LCDs) of $p / C I P /$ $\mathrm{NCoA} / \mathrm{CBP}$. a, A repeated leucine-rich domain is required for protein-protein interactions between $\mathrm{p} /$ CIP, CBP, NCoAs and nuclear receptors. The sequences of some of these motifs are noted, with the core hexapeptide motifs indicated by brackets. Helical wheels of NCOA-1 LCD2 and CBP LCD6 are shown. $\mathbf{b}$, Mutation of amino acids 70-73 in CBP (QLSELL $\rightarrow$ QLAAAA) resulted in a complete loss of ligand-dependent interaction with T3R. c, Left, assessment by the yeast two-hybrid assay of interactions between the NCoA-1 nuclearreceptor-interaction domains (residues 635-760) with nuclear receptors; centre, mutations of the LCD2 motif (RLHRLL $\rightarrow$ RLAAAA) abolished liganddependent interaction, whereas peptides encompassing LCD2 (37 amino acids) alone or LCD6 (59 amino acids) were sufficient for ligand-dependent interaction; right, 24-mer peptides encompassing LCD1, LCD6, or a control peptide were tested for ability to inhibit binding of ${ }^{35} \mathrm{~S}$-labelled NCoA interaction domain fragment (amino acids 635-760) to liganded RAR with TTNPB $(1 \mu \mathrm{M})$. d, e, Functional effects of plasmids expressing mutations in LCD2 $(\mathrm{HRLL} \rightarrow$ AAAA) and LCD3 (RYLL $\rightarrow$ AAAA) of NCoA-1 on rescue of inhibition by microinjected anti-NCoA-1 $\lg (\alpha-1)$ on retinoic-acid- (d) and oestrogen (e) -dependent transcription. In parts c-d, $\mathrm{IH} 1, \mathrm{IH} 2$ etc. represent the equivalent LCDs. d

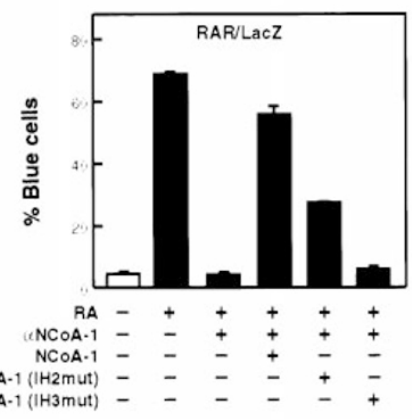

e

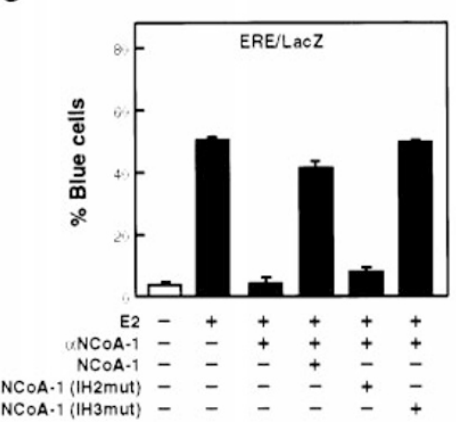

of retinoic acid and IFN- $\gamma$ gave reciprocal inhibition of retinoic acid- and interferon-dependent reporter gene expression (Fig. 6c). However, the addition of CBP N' P1 peptide relieved inhibition of RAR-dependent transcription by IFN- $\gamma$, consistent with the ideas that this inhibition represents, at least in part, competition for CBP co-activator complexes, analogous to that proposed for AP-1 and nuclear receptors ${ }^{3}$. Our results are consistent with the hypothesis that different 'motifs' are used in assembling CBPdependent complexes by different classes of transcription factors and can be used to block specific signal-transduction pathways.

\section{Discussion}

Our data indicate that $\mathrm{p} / \mathrm{CIP}$, a novel factor with which a significant component of the $\mathrm{CBP} / \mathrm{p} 300$ in the cell is associated, is apparently required for regulated transcription by nuclear receptors and other CBP-dependent factors, including STAT and AP-1. Our findings show that both the CBP/p/CIP complex and NCoA-1 are required to allow full ligand-activated gene transcription in the cell types that we have examined, whereas NCoA-1/SRC-1 is not required for other CBP-dependent transcription. Because CBP can associate with many additional factors, including Myb (ref. 35), YY1 (ref. 36), SREBP (ref. 37), MyoD and the HLH factors (ref. 9), p/CIP and CBP may be components of a larger complex critical for integration of several signal-transduction pathways. The existence of a co-integrator complex has obvious implications with respect to enhancer-specific functions and expanded ability to respond to diverse regulatory pathways. Whether $\mathrm{p} / \mathrm{CIP}$ is required for all CBPdependent transcription factors remains to be established. It has been shown that the $\mathrm{N}$ terminus of $\mathrm{CBP}$ alone is sufficient to potentiate CREB function in transient co-transfection assays ${ }^{38,39}$, but the $\mathrm{C}$ terminus is also required in transcription assays in vitro ${ }^{40}$. Together, our findings suggest that conformational alterations in 
a

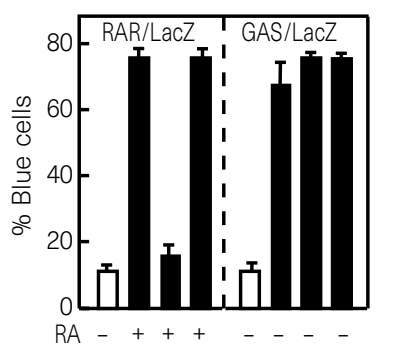

$\operatorname{lnf} \gamma-{ }_{-}-+++$

NCOA-1 LCD4 - + + - - + -

Control P b

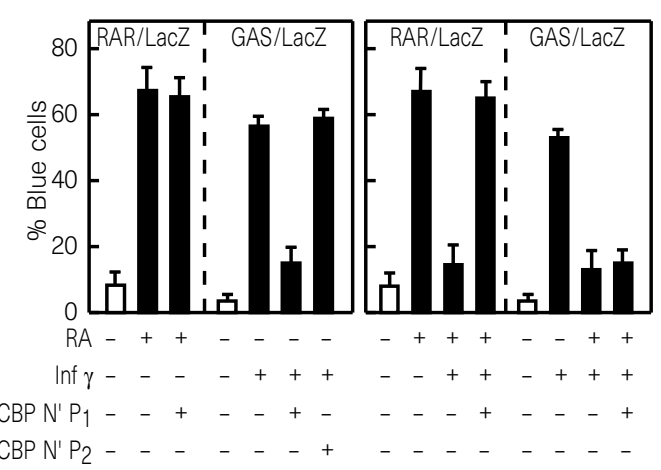

d

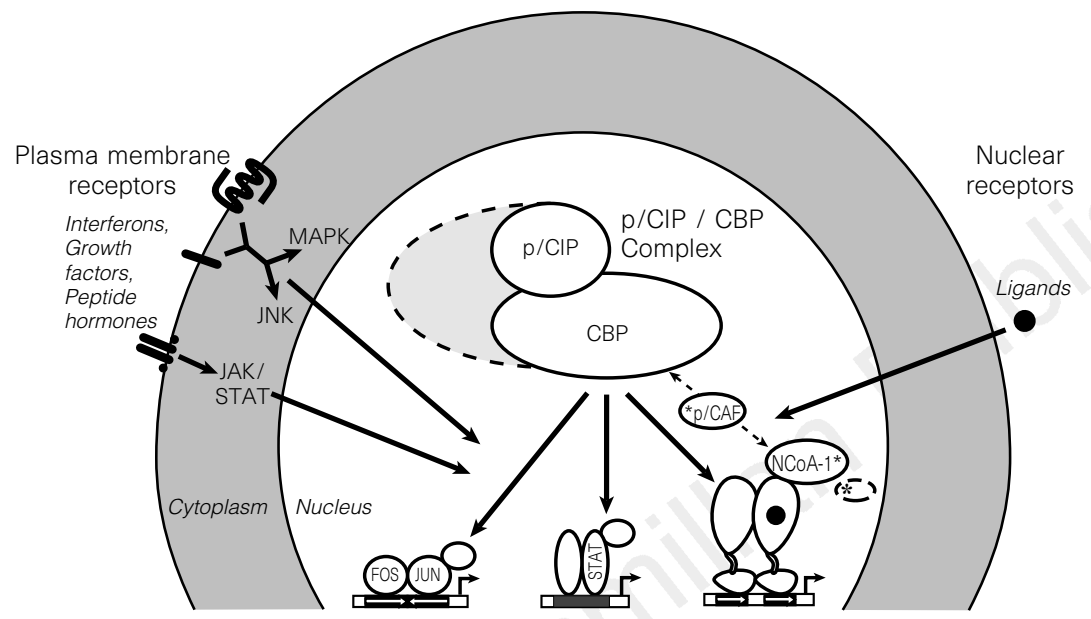

Figure 6 Distinct helical motifs block transcriptional effects of specific signal transduction pathways. a, Ability of a 19-mer peptide corresponding to NCoA-1 LCD4, but not a control peptide (CBP-622, control P) inhibits retinoic-acid-induced, but not IFN $\gamma$-induced gene expression. $\mathbf{b}$, Effects of microinjection of the $\mathrm{N}$-terminal 22 amino acids of CBP (CBP N'-P1), a synthetic Nterminal CBP peptide, on retinoic-acid and interferon gene-activation events. A synthetic peptide corresponding to the identical peptide lacking the eight amino terminal amino acids (CBP N'-P2) failed to inhibit interferon-dependent gene-activation events. c, Similarly, IFN- $\gamma$ inhibition of retinoic-acid-dependent activation of the RARE/LacZ reporter (right) was abolished by coinjection of the CBP N'-P1 peptide, which had no effect on retinoic-acid-dependent inhibition of the GAS/LacZ reporter by activated retinoic-acid reporter. $\mathbf{d}$, Model of $\mathrm{p} / \mathrm{CIP} / \mathrm{CBP}$ (p300) function. We suggest that several signal-transduction pathways that are mediated by specific transcription factors require a functional $\mathrm{p} / \mathrm{CIP}$, $\mathrm{CBP} / \mathrm{p} 300$ complex, and potentially $\mathrm{p} / \mathrm{CAF}$, with each partner being required, but not sufficient, to mediate transcriptional effects. Nuclear-receptor-specific requirements for distinct protein-protein associations through specific helical motifs (LCDs) is indicated.
CBP holoprotein, perhaps in part contributed by p/CIP, modulate interactions with transcription factors and associated regulatory proteins, including protein kinases and histone acetylases ${ }^{1,2,41,42}$. Furthermore, p/CAF is capable of interacting with NCoA-1 (E. Korzus and M.G.R., unpublished) as well as $\mathrm{CBP}^{41}$, although the role of this histone acetylase in mediating transcriptional activation by nuclear receptors is unclear.

The nuclear-receptor and CBP-interaction domains within NCoA-1, NCoA-2 and p/CIP $(\sim 80-100$ amino acids $)$ contain highly related, putative helical motifs (referred to as LCDs) that are required and, at least in some cases, sufficient for interaction, but which mediate receptor-specific functions. Thus, the third helical motif in the nuclear-receptor-interaction domain of NCoA-1 is used differentially, being absolutely required for retinoic-acid function, but not for oestrogen-receptor-dependent gene activation. These data provide an insight into the molecular basis of specificity of nuclear-receptor-dependent transcriptional responses. Similar LCDs are present in CBP and in most of the factors that have been cloned based on their ability to interact with liganded nuclear receptors, including TIF-1 and RIP-140 (refs 23, 28). Thus, many factors may associate with the complexes formed on receptor homo- or heterodimers bound to their cognate DNA site and constitute an aspect of this specificity. Assembly of larger complexes of proteins, based on these interaction motifs, could provide a basis for receptor-specific and regulated aspects of nuclear-receptor function (Fig. 6d).

The finding of the similar helical interaction motifs in $\mathrm{CBP} / \mathrm{p} /$ $\mathrm{CIP} / \mathrm{NCoAs}$ and other nuclear-receptor-interacting factors has allowed the use of such motifs in selective blockade of gene activation events in response to specific signal-transduction pathways. Thus, peptides corresponding to CBP-interaction motifs can selectively block nuclear receptor or STAT-1 function. The actions of specific inhibitory peptides have provided additional evidence that partitioning of $\mathrm{CBP}^{3,12}$, at least in part, accounts for trans-repression of nuclear receptor/STAT/AP-1 pathways. The demonstration that specific interaction motifs can selectively block gene activation by specific signal-transduction pathways has potentially intriguing applications to the study of signalling in development, as well as therapeutic implications.

\section{Methods}

Isolation of interacting proteins. Expression cloning was done using a ${ }^{32} \mathrm{P}-$ labelled GST-CBP $(2,058-2,170)$ or ${ }^{32}$ P-labelled GST-ER ligand-bindingdomain probe in the presence of $10^{-6} \mathrm{M}$ oestradiol ${ }^{3}$. cDNAs corresponding to p/CIP, NCoA-1 and NCoA-2 were assembled into Bluescript expression vector and tested by in vitro translation, generating products of $M_{\mathrm{r}} \sim 160 \mathrm{~K}$.

Yeast two-hybrid interaction assays. The yeast strain EGY 48 , the LexA- $\beta$ galactosidase reporter construct (PSH18-34) and the B42 parental vectors (PEG 202 and PJG 4-5) have all been described ${ }^{3,43}$. Nuclear-receptor ligandbinding domains and various CBP fragments were subcloned into PEG 202 bait vector. DNA fragments encompassing the entire p/CIP-NCoA-1 or NCoA-2 proteins were generated either by using an appropriate restriction digest or by PCR and subcloned into PJG 4-5 prey vectors. EGY 48 cells were transformed with the lac $Z$ reporter plasmid pSH 18-34 with the appropriate bait and prey vectors, and plated out on Ura-His-Trp medium containing $2 \%$ galactose. Isolated yeast colonies were then allowed to grow in the same liquid medium and assayed for $\beta$-galactosidase as described ${ }^{44}$.

Transient transfections and reporter assays. Transfection was done in either HeLa or CV-1 cells using the standard calcium phosphate procedure. Typically, $1 \mu \mathrm{g}$ RARE- or ERE-driven luciferase reporter was co-transfected with $1 \mu \mathrm{g}$ of the indicated vectors. The final DNA concentration was adjusted to $10 \mu \mathrm{g}$ per $60-\mathrm{mm}$ dish, incubated for $24 \mathrm{~h}$, and the appropriate ligands administered for $24 \mathrm{~h}$ at $10^{-6} \mathrm{M}$. Alternatively, co-transfections were done using PCMX p/CIP, NCoA-1 or PCR-generated NCoA-1 fragments fused to the 
GAL4 DNA-binding domain (residues 1-147). Cells were transfected with $1.0 \mu \mathrm{g}$ (UAS) ${ }_{6}$-luciferase reporter and the indicated concentrations of GAL4 fusion proteins and collected $48 \mathrm{~h}$ later.

Generation of affinity-purified NCoA antibodies and peptides. cDNA fragments corresponding to $\mathrm{p} / \mathrm{CIP}(544-851) \mathrm{NCoA}-1$ (424-789), and NCoA$2(787-1,129)$ were subcloned into the PM vector containing an in-frame His tag and recombinant His-tagged proteins were generated and purified by nickel chelate chromatography. Purified recombinant proteins were injected into rabbits and antibodies generated and affinity-purified using standard procedures ${ }^{45}$. Peptide sequences, generated (Research Genetics) and confirmed by mass spectroscopy, include: NCoA-1 LCD1 (amino acids 631-647); NCoA-1 LCD2 (687-706); NCoA-1 LCD4 (907-926); CBP N'P1 (1-19); CBP N'P2(8-19). GST-interaction assays, immunoprecipitations and enzymatic assays. Whole-cell extracts were prepared by lysing cells in NET-N buffer containing $50 \mathrm{mM}$ Tris (pH 7.6), $5 \mathrm{mM}$ EDTA, $0.3 \mathrm{M} \mathrm{NaCl}, 1 \mathrm{mM}$ DTT, $0.1 \% \mathrm{NP}-40$ and protease inhibitors $\left(0.2 \mathrm{mM}\right.$ PMSF, $10 \mu \mathrm{g} \mathrm{ml}^{-1}$ each of leupeptin, pepstatin and aprotinin), centrifuged at $30 \mathrm{~K}$ for $1 \mathrm{~h}$ at $4{ }^{\circ} \mathrm{C}$; the supernatant was stored at $-80^{\circ} \mathrm{C}$.

GST-RAR(143-462), GST-ER(251-595) and GST-CBP(2,058-2,170) were generated as described ${ }^{3} .25 \mu \mathrm{l}$ GST-Sepharose beads containing $10 \mu \mathrm{g}$ GST recombinant proteins were incubated in the presence or absence of the appropriate ligand for $30 \mathrm{~min}$ at room temperature, followed by the addition of $1 \mathrm{mg}$ cell extract and incubated for an additional hour at $4{ }^{\circ} \mathrm{C}$. Complexes were then centrifuged, washed three times in NET-N buffer, separated by SDSPAGE, and western blotted with the appropriate antibodies $\left(1 \mu \mathrm{g} \mathrm{ml}^{-1}\right)$. For co-immunoprecipitation, $1 \mathrm{mg}$ cell extract was incubated with $2 \mu \mathrm{g} \mathrm{p} / \mathrm{CIP}$ or $\mathrm{NCoA}$ antibody for $2 \mathrm{~h}$ at $4{ }^{\circ} \mathrm{C}$. Immune complexes were then precipitated with protein A-Sepharose $(50 \% \mathrm{w} / \mathrm{v})$. Protein complexes were separated by SDS$\mathrm{PAGE}^{46}$ and western blotted using $1 \mu \mathrm{g} \mathrm{ml}^{-1}$ of an anti-CBP/P300 monoclonal antibody (UBI). For in vitro competition assays, the indicated peptides were incubated with in vitro translated NCoA-1 before GST interaction with RAR. Mutagenesis. Mutations in NCoA-1 and CBP were introduced by sitedirected mutagenesis using a quick-change mutagenesis kit according to the manufacturer's instructions (Stratagene). Double-stranded oligonucleotides were designed so that the wild-type sequence corresponding to amino acids 695-698 and 756-759 in PCMX NCoA-1 and PJG4-5-4 NCoA-1(635-760) were substituted with alanines. A similar protocol was used to replace amino acids 70-73 in PJG4-5 CBP(1-101).

Single-cell microinjection assay. Insulin-responsive Rat-1 fibroblasts were seeded on acid-washed glass coverslips at subconfluent density and grown in MNE/F12 medium supplemented with $10 \%$ fetal bovine serum, gentacin and methotrexate. Before injection, cells were rendered quiescent by incubation in serum-free medium for $24-26 \mathrm{~h}$. Plasmids were injected into the nuclei of cells at $100 \mu \mathrm{g} \mathrm{ml}^{-1}$. Peptides were injected at $200 \mu \mathrm{M}$. Either preimmune IgG of the appropriate species, or antibodies directed against p/CIP, NCoA-1 or NCoA-2, were co-injected and the injected cell unambiguously identified. Microinjections were done using an Eppendorf semiautomated microinjection system mounted on an inverted Zeiss microscope. About $1 \mathrm{~h}$ after injection, cells were stimulated, where indicated, with the appropriate ligand. In rescue experiments, cells were stimulated with ligand $6 \mathrm{~h}$ after injection to allow protein expression. After overnight incubation, cells were fixed and stained to detect injected IgG and $\beta$-galactosidase expression ${ }^{3,47}$. Injected cells were identified by staining with tetramethylrhodamine-conjugated donkey antirabbit IgG. Data accession numbers of $\mathrm{p} / \mathrm{CIP}$ and NCoA-2 sequences are AF000581 and AF000582, respectively.

Received 14 January; accepted 6 May 1997.

1. Ogryzko, V. V., Schiltz, R. L., Russanova, V., Howard, B. H. \& Nakatani, Y. The transcriptional coactivator p300 and CBP are histone acetyltransferases. Cell 87, 953-960 (1996).

2. Bannister, A. J. \& Kouzarides, T. The CBP coactivator is a histone acetyltransferase. Nature 384, 641643 (1996).

3. Kamei, Y. et al. A CBP integrator complex mediates transcriptional activation and AP-1 inhibition by nuclear receptors. Cell 85, 1-12 (1996).

4. Yao, T.-P., Ku, G., Zhou, N., Scully, R. \& Livingston, D. M. The nuclear hormone receptor coactivator SRC-1 is a specific target of p300. Proc. Natl Acad. Sci. USA 93, 10626-10631 (1996).

5. Hanstein, B. et al. $\mathrm{p} 300$ is a component of an estrogen receptor coactivator complex. Proc. Natl Acad. Sci. USA 93, 11540-11545 (1996).

6. Chakravarti, D. et al. Role of CBP/p300 in nuclear receptor signalling. Nature 383, 99-103 (1996).

7. Kwok, R. P. et al. Nuclear protein CBP is a coactivator for the transcription factor CREB. Nature 370, 223-226 (1994).

8. Arias, J. et al. Activation of cAMP and mitogen-responsive genes relies on a common nuclear factor. Nature 370, 226-229 (1994)
9. Eckner, R., Yao, T.-P., Oldread, E. \& Livingston, D. M. Interaction and functional collaboration of p300/CBP and bHLH proteins in muscle and B-cell differentiation. Genes Dev. 10, 2478-2490 (1996). 10. Bhattacharya, S. et al. Cooperation of Stat 2 and $\mathrm{p} 300 / \mathrm{CBP}$ in signalling induced by interferon- $\alpha$. Nature 383, 344-347 (1996).

11. Zhang, J. J. et al. Two contact regions between Statl and CBP/p300 in interferon $\gamma$ signaling. Proc. Natl Acad. Sci. USA 93, 15092-15096 (1996).

12. Horvai, A. E. et al. Nuclear integration of JAK/STAT and ras signaling by CBP and p300. Proc. Natl Acad. Sci. USA 94, 1074-1079 (1997).

13. Chambon, P. The retinoid signaling pathway: molecular and genetic analyses. Semin. Cell Biol. 5, 115125 (1994).

14. Beato, M., Herrlich, P. \& Schütz, G. Steroid hormone receptors: many actors in search of a plot. Cell 83, 851-857 (1995).

15. Tsai, M. J. \& O’Malley, B. W. Molecular mechanisms of action of steroid/thyroid receptor superfamily members. Annu. Rev. Biochem. 63, 451-486 (1994).

16. Danielian, P. S., White, R., Lees, J. A. \& Parker, M. G. Identification of a conserved region required for hormone-dependent transcriptional activation by steroid hormone receptors. EMBO J. 11, 10251033 (1992).

17. Durand, B. et al. Activation function 2 (AF-2) of retinoic acid receptor and 9-cis retinoic acid receptor: presence of a conserved autonomous constitutive activating domain and influence of the nature of the response element on AF-2 activity. EMBO J. 13, 5370-5380 (1994).

18. Barettino, D., Vivanco Ruiz, M. M. \& Stunnenberg, H. G. Characterization of the ligand-dependent transactivation domain of thyroid hormone receptor. EMBO J. 13, 3039-3049 (1994).

19. Tone, Y., Collingwood, T. N., Adams, M. \& Chatteriee, V. K. Functional analysis of a transactivation domain in the thyroid hormone beta receptor. J. Biol. Chem. 369, 31157-31161 (1994).

20. Bourguet, W., Ruff, M., Chambon, P., Gronemeyer, H. \& Moras, D. Crystal structure of the ligandbinding domain of the human nuclear receptor RXR- $\alpha$. Nature 375, 377-382 (1995).

21. Renaud, J.-P. et al. Crystal structure of the RAR- $\gamma$ ligand-binding domain bound to all-trans retinoic acid. Nature 378, 681-689 (1995).

22. Wagner, R. L. et al. A structural role for hormone in the thyroid hormone receptor. Nature 378, 690696 (1995).

23. Halachmi, S. et al. Estrogen receptor-associated proteins: possible mediators of hormone-induced transcription. Science 264, 1455-1458 (1994).

24. Cavailles, V. et al. Nuclear factor RIP140 modulates transcriptional activation by the estrogen receptor. EMBO J. 14, 3741-3751 (1995)

25. Kurokawa, R. et al. Polarity-specific activities of retinoic acid receptors determined by a co-repressor. Nature 377, 451-454 (1995).

26. Fondell, J. D., Ge, H. \& Roeder, R. G. Ligand induction of a transcriptionally active thyroid hormone receptor coactivator complex. Proc. Natl Acad. Sci. USA 93, 8329-8338 (1996).

27. Lee, J. W., Ryan, F., Swaffield, J. C., Johnston, S. A. \& Moore, D. D. Interaction of thyroid-hormone receptor with a conserved transcriptional mediator. Nature 374, 91-94 (1995).

28. Le Douarin, B. et al. The N-terminal part of TIF1, a putative mediator of the ligand-dependent activation function (AF-2) of nuclear receptors, is fused to B-ref in the oncogenic protein T18. EMBO J. 14, 2020-2033 (1995)

29. Onate, S. A., Tsai, S. Y., Tsai, M.-J. \& O’Malley, B. W. Sequence and characterization of a coactivator for the steroid hormone receptor superfamily. Science 270, 1354-1357 (1995).

30. Cavailles, N., Dauvois, S., Danielian, P. S. \& Parker, M. G. Interaction of proteins with transcriptionally active estrogen receptors. Proc. Natl Acad. Sci. USA 91, 10009-10013 (1994)

31. Voegel, J. J., Heine, M. J. S., Zechel, C., Chambon, P. \& Gronemeyer, H. TIF2, a $160 \mathrm{kDa}$ transcriptional mediator for the ligand-dependent activation function AF-2 of nuclear receptors. $E M B O J .15,3667-$ 3675 (1996).

32. Hong, H., Kohli, K., Trivedi, A., Johnson, D. L. \& Stallcup, M. R. GRIP1, a novel mouse protein that serves as a transcriptional coactivator in yeast for the hormone binding domains of steroid receptors. Proc. Natl Acad. Sci. USA 93, 4948-4952 (1996).

33. Smith, C. L., Oñate, S. A., Tsai, M.-J. \& O'Malley, B. W. CREB binding protein acta synergistically with steroid receptor coactivator-1 to enhance steroid receptor-dependent transcription. Proc. Natl Acad. Sci. USA 93, 8884-8888 (1996).

34. Geourjon, C. \& Deleage, G. SOPM: a self optimised prediction method for protein secondary structure prediction. Protein Eng. 7, 157-164 (1994).

35. Dai, P. et al. CBP as a transcriptional coactivator of c-Myb. Genes Dev. 10, 528-540 (1996).

36. Lee, J.-S. et al. Relief of YY1 transcriptional repression by adenovirus E1A is mediated by E1Aassociated protein $\mathrm{p} 300$. Genes Dev. 9, 1188-1198 (1995).

37. Oliner, J. D., Andresen, J. M., Hansen, S. K., Zhou, S. \& Tjian, R. SREBP transcriptional activity is mediated through an interaction with the CREB-binding protein. Genes Dev. 10, 2903-2911 (1996).

38. Bisotto, S., Minorgan, S. \& Rehfus, R. P. Identification and characterization of a novel transcriptional activation domain in the CREB-binding protein. J. Biol. Chem. 271, 17746-17750 (1996).

39. Swope, D. L., Mueller, C. L. \& Chrivia, J. C. CREB-binding protein activates transcription through multiple domains. J. Biol. Chem. 271, 28138-28145 (1996).

40. Nakajima, T., Uchida, C., Anderson, S. F., Parvin, J. D. \& Montminy, M. Analysis of a cAMPresponsive activator reveals a two-component mechanism for transcriptional induction via signaldependent factors. Genes Dev. 11, 738-747 (1997).

41. Yang, X.-Y., Ogryzko, V. V., Nishikawa, J., Howard, B. H. \& Nakatani, Y. A p300/CBP-associated factor that competes with the adenoviral oncoprotein E1A. Nature 382, 319-324 (1996).

42. Nakajima, T. et al. The signal-dependent coactivator CBP is a nuclear target for pp90 rsk. Cell 86, 465474 (1996).

43. Gyuris, J., Golemis, E., Chertkov, H. \& Brent, R. Cdil, a human G1 and S phase protein phosphatase that associates with Cdk2. Cell 75, 791-803 (1993).

44. Ausubel, F. M. et al. Current Protocols in Molecular Biology (Greene, New York, 1994).

45. Harlow, E. \& Lane, D. Antibodies: A Laboratory Manual (Cold Spring Harbor Laboratory, Cold Spring Harbor, NY, 1988).

46. Laemmle, E. K. Cleavage of structural proteins during the assembly of the head of bacteriophage T4. Nature 227, 680-685 (1970).

47. Rose, D. W., McCabe, G., Feramisco, J. R. \& Adler, M. Expression of c-fos and AP-1 activity in senescent human fibroblasts is not sufficient for DNA synthesis. J. Cell. Biol. 119, 1405-1411 (1992).

Acknowledgements. We thank $\mathrm{N}$. Assa-Munt for discussions and help with computer analysis of protein structures; A. Aggarwal, T.-M. Mullen, J. Gemsh and C. Nelson for assistance; M. Parker for the RIP 140 cDNA clone, P. Myer for help in preparing the figures; and B. Stawiarski for help in preparing the CDNA clone, P. Myer for help in preparing the figures; and B. Stawiarski for help in preparing the
manuscript. This work was supported by an American Diabetes Association career development award manuscript. This work was supported by an American Diabetes Association career development award
(to D.W.R.), by the National Cancer Institute of Canada (J.T.), by a Damon Runyon-Walter Winchell Foundation fellowship (J.I.) and by the Swedish Cancer Society (S.W.). M.G.R. is an investigator with the Howard Hughes Medical Institute. These studies were suppported by a US Army Breast Cancer Research Program and grants from the NIH to C.K.G. and M.G.R.

Correspondence should be addressed to D.W.R. and requests for materials to M.G.R. 